ARTICLES

\title{
MONGOLIA AND INDIA
}

\author{
O. Nyamdavaa
}

\section{PAST CONTACTS}

\section{Origins}

The relations between Mongolia and India are believed to have some very deep roots. To cite but a few persons in our two countries, according to Jawaharla! Nehru, India harbors especially warm feelings toward Mongolia because "our relations go back into the distant past of more than 1500 years." Professor P.C. Chowdhary of Dibrugarh University has stated that the first link between the two countries dates back to the fifth century $\mathrm{BC}^{2}$. More specifically, Mr. Mohanlal Yadu of the Government's College Raipur Ram concluded that "a discovery of seventeen rock paintings in three shelters in the dense forests of Chitwa Dongri [Leopard Hill, 114 km from Raipur, Madhya Pradesh] has revealed startling evidence of the presence of Mongolian settlers in Central! India during the Neolithic Age [2500 to $600 \mathrm{BC}$ ], perhaps long before the advent of the Gupta period "3 A. Amar, Mongolian prime minister in the 1920s, opined in his brief history of Mongoiia that Mongols originated in India ${ }^{4}$ And the Ven. Kushok Bakula, Ambassador of India to Mongolia, has pointed out that the people

Living in India's Himalayan region have racial, cultural, and religious affinity to the Mongols. ${ }^{5}$

It is specifically in the northeastern part of India's Himalayan region that evidence of ancient ties is believed to be found. Some thirty million people live there who, according to Lai Than kola, former Chief Minister of Mizoram, are Mongoloid and descended from Mongols. ${ }^{6}$ They are currently members of some twenty-nine tribes. Some Indians believe that the ancestors of these people came from Mongolia and maintained some of their customs and habits. As for evidence, they point to people living in Manipur, Arnuchal Pradesh, and Mizoram.

\footnotetext{
${ }^{1}$ Nehru, speech given at the Fifteenth Session of the UN General Assembly October 3, 1960.

${ }^{2}$ The Mongol Messenger, June 8, 1993.

${ }^{3}$ Northern India Patnxa, June 27, 1982.

${ }^{4}$ A. Amar, Mongolyn Tovch Tuukh (Ulaanbaatar : Ulsyn Khevlelijn Khoroo, 1989), 22-23.

5 'Perspectives on Mongolia', edited by R.C.Shartna, Seema publications, p. 142.

${ }^{6}$ Nava Bharat Times, September 8, 1991.
} 
The sound of the Pena, a Manipur musical instrument, is very similar to the Mongolian Morin khuur [horse head fiddle]. The Manipuri form of wrestling, mina is quite similar to the Mongolian both. The Mongolian hair cutting ceremony for children when they are tree to five years old is also found there. Objects quite similar to the Mongolian woo [cairns] are also present in Manipur. The Mongolian tradition of passing a knife with the handle facing the recipient is also observed in Manipur. Finally, people point out that the so-called blue spot, a Mongolian birthmark, is also found on children living in India's northeast.

There seem to be three kinds of notions about their origins currently held among the people of Northeast India. One holds that the troops sent by Khubilai Khan to Myanmar and Northeast India were never recalled and remained there. A similar notion has Mongol troops stay behind in the lowlands, like in the district of Mongolpuri in Deihi, and in Jammu Kashmir, who later migrated to the northeastern hill regions. A third opinion states flatly that Mongols originated in India, a notion shared by Amar, as previously mentioned. It should be stressed that none of these conjectures has ever been proven and that there has yet to be a scientific investigation into this fascinating subject.

\section{Religion and Culture}

According to Indian historians, Buddhism spread in the Indo-Genetic valley during the lifetime of the Buddha. King Ashoka deputized a group of monks to Gandhara to propagate the dharma. The first missionary who took Buddhism to Central Asia was Vairochana, a Kashmiri scholar, who built the first monastery at Khotan. ${ }^{7}$ as Buddhism spread in Central Asia; it came to the notice of the Xiongnu, an ancient Mongolian tribe, who had direct relations with Central Asia. Soon conversions took place, and Mongolian monks undertook the arduous journey to India across the Himalayas, staying overnight in caves and having to contend with wolves and other wild animals. Once they were in India, these Mongolian pilgrims traveled to Nalanda University, the largest residential university in ancient India with 9500 students and 1510 teachers and staff, where they received instruction free of charge.

These details have been chronicled by the Chinese pilgrims Faxian (5th century $)^{8}$, Xuanzang (fl. 629-645) ${ }^{9}$, and Yijing (fl. 675-695) ${ }^{10}$. Both Xuanzang and

\footnotetext{
${ }^{7}$ F.M. Hassnain, Buddhist Kashmir.

${ }^{8}$ Link (newsweekly) March 3, 1991, India page 22-23.

${ }^{9}$ Ibid, page $22-23$

${ }^{10} \mathrm{Ibid}$, page $22-23$
} 
Yijing saw at Nalanda students from a number of foreign countries, like Korea, Mongolia, Tokhara, China, and Tibet. Yijing counted fifty-six foreign students. Pandit Jawaharlal Nehru also mentioned that "it [Nalanda University] specialized in postgraduate study and attracted students from China, Japan, Tibet, Mongolia, Korea, and Bokhara." ${ }^{11}$ The Great Khan Ogedei (r. 1229-1241) supported Buddhism and began to build Buddhist monasteries and big sputa in the city of Karakorum which had been proclaimed by his father, Chinggis Khan, as the capital of Mongolia in 1220.

His successor, Monkh Khan, further strengthened the religious and cultural ties between Mongolia and India. He appointed the Kashmirian monk Namu to the newly created position of State Teacher for which he used the Sanskrit word guru. Iphtikhir Eddin Mukhamed, a Persian scholar and tutor of Monkh Khan, translated the tale of Calita and Dimna, a part of the Indian Panchtantra, from Persian into Mongolian and assigned it as reading to Monkh Khan.

Buddhist influence, and through it ties to Indian culture, reached a high point during- the long reign of Khubilai Khan (r. 1220-1296). Sonam Gara, a wellknown translator, translated the philosophical and moral treatise, Subashid or Subhasitaratnonidhi, by Saya Pandita Kunga Gyaltsan from the Tibetan. One of the major efforts in the dissemination of Buddhism was the translation of books from Sanskrit, Tibetan, and Uyghur into Mongolian and their subsequent printing. By the beginning of the fourteenth century all the principal works on Buddhism had been translated and printed in runs of one to two thousand copies each. A major figure in this endeavor was Choiji Odzer, a Mongolian scholar, philosopher and poet, who not only translated works but also provided his own commentaries. During the reign of the last Mongol Great Khan, Ligdan (16041634), the largest single translation project during that or any other time was undertaken with the creation of the Mongolian Ganjur and Danjur, consisting of 333 large volumes, representing translations from various Indian languages, first into Tibetan and then into Mongolian. ${ }^{12}$ The Ganjur is attributed to the Buddha while the Danjur is a collection of thousands of works by other Indian pundits and saints. The Mongolian Danjur is far richer than its Tibetan counterpart because it includes many Indian texts, translated both from Sanskrit and Chinese that are not included in the Tibetan Danjur. Finally, mention should be made of the Bog do Jebtsundamba Hutukhtu Zanabazar, an outstanding artist,

\footnotetext{
${ }^{11}$ India and Mongolia: Experience and Interactions, by R.C. Sharma and Sh. Bira, page 51.

${ }^{12}$ The process of preparing woodblocks for printing was interrupted by war, and the actual printing of the entire Mongolian Ganjur and Danjur did not occur until the second half of the eighteenth century.
} 
who created the Soyombo (Svayambhu) script for religious purposes. This script was derived from the Deva-nagari or Landza script with additional symbols and markings to make it more suitable for the Mongolian Khalkha dialect. The Soyombo script retained its high esteem among Mongols as witnessed by the Soyombo phoneme ohm found in Mongolia's national emblem.

\section{Mongol Attacks on India}

According to Mongolian and foreign sources, Chinggis Khan arrived in 1221 on the banks of the Indus River. There, instead of advancing into India, he returned to Mongolia. Toward the end of that century, however, the first Mongol raids into India took place. Shortly after Aladdin's accession to power, in 1297-1298 a Mongol invasion into the Punjab took place, followed by a major attack into Siwistan. Both invasions were repulsed. Then in 1303 the Mongols actually invaded the city of Delhi until Alauddin managed to break the siege. ${ }^{13}$ in subsequent times, several more Mongol invasions of India took place, and in some cases Mongols stayed behind and settled down. Dr. Satish Garg of Delhi University remarked that the district of Mughalpur or Mongolpur in Delhi dates back to the time of Jalaluddin Khilji. ${ }^{14}$ One can add to this a statement by Mrs. Mansura Haider of Aligarh Muslim University: "Jalaluddin ... knew the art of fighting against the Mongols. It was the same Jalaluddin who tried to solve the Mongol problem through the age-old method of matrimonial alliances. Alghu, grandson of Chinggis Khan, was converted to Islam and subsequently married to the sultan's daughter. Alghu's followers were given stipends and rewards and ail of them were settled in the territories of Ghayaspur, Kalogeria and Undraped. Although some of these people returned to their own country, unable to face the climatic conditions in India, the remaining Mongols continued to enjoy grants of villages and stipends and were known as new Muslims." ${ }^{15}$ These new settlers faced a bleak future. They were kept in great poverty and eventually became a danger to the state. A conspiracy among them was discovered, and Aladdin commanded that all new Muslims, thirty to forty thousand, be kilted. The order was earned out and their property stolen. ${ }^{16}$ Nowadays Mongolpuri has lost much of its earlier character. It has been developed into a combined residential and industrial district.

\footnotetext{
${ }^{13}$ Encyclopedia Britennica, volume 21.

${ }_{14}^{14}$ Perspectives on Mongolia, edited by R.C.Sharma, page 165.

15 op- cit., 42.

${ }^{16}$ Stanley Lane-Poole, Medieval India, 96-97.
} 


\section{The Great Moghul Period in India}

The Delhi Sultanate was replaced in 1562 by the Great Moghul period which lasted until the British took over in 1857. Babur, the founder of the new dynasty, belonged to the family of Chagaadai Khan, one of Chinggis Khan's sons. The Moghul rulers, from Babur to Aurangzeb, contributed greatly to India's stature as a great nation. Through good administration, India enjoyed a long period of peace and prosperity. The Moghuls improved the means and methods of warfare and introduced gunpowder artillery, but they also patronized literature and the fine arts. India's international relations revived during this period in which Afghanistan remained a part of the Moghul Empire. Beyond it, communications were established with Persia, Central Asia, and points west. These renewed ties with the outside world led to the development of foreign trade and general prosperity in India.

Perhaps the Moghuls' greatest achievement lay in the field of religion. Like Chinggis Khan himself, the Moghul rulers were renowned for their religious tolerance. Serious efforts to gain the loyalty and support of the country's Hindu majority paid off, and the spirit of accommodation between the Hindu and Muslim populations that had existed before the Moghul period, was preserved.

\section{CONTEMPORARY RELATIONS}

\section{The Socialist Period}

At the beginning of this century, both Mongolia and India were under colonial rule. The northern part of Mongolia gained its independence from Manchu control in 1911, and India shed its British colonial status in 1947. Soon thereafter, in 1955, the two countries established diplomatic relations. Mr. Bayanbatyn Ochirbat became the first ambassador to India who presented his credentials to Dr. Rajendra Prasad, the first Indian president, on January 29, 1956. Simultaneously, R.K. Nehru, the Indian ambassador to China, was concurrently appointed the first ambassador to Mongolia and presented his credentials to J. Sambuu, chairman of the presidium of the Great People's Khural, on May 9, 1956. Thus India became the first non-socialist nation to recognize Mongolia, and it remained so for a long time thereafter. The Mongolian embassy in New Delhi, therefore, took on extraordinarily great importance as it served as the most important channel of information between Mongolia and the entire non-socialist world and also as the training ground for many of Mongolia's diplomats who later rose to high positions. 


\section{Nehru's Views on Mongolia}

Pandit Jawaharlal Nehru, India's firs prime minister was a great friend of Mongolia. At the fifteenth session of the United Nations General Assembly on October 3, 1960, Nehru asked rhetorically why, when so many other countries were being admitted to the world body, Mongolia was being excluded. ${ }^{17}$ Later, Nehru wrote admiringly of the time of the Mongol world empire when "crowds of merchants and artisans and learned men and missionaries came [to Karakorum, the capital of Mongolia]."18 In another book, Nehru wrote of the "great Mongol race" that spread all over Eastern and Central Asia. ${ }^{19}$ Nehru's sentiments toward Mongolia have been reciprocated. He has been given a place of prominence in Mongolian books on world history. On the occasion of his birth centennial in 1989, celebrations were held and a set of commemorative stamps was issued. His book Glimpses of World History has been translated into Mongolian and in 1995 the new Production and Service Technical College in Ulaanbaatar was named after Nehru's son, Rajiv Gandhi.

\section{The Outlook}

Last year the fortieth anniversary of our two countries' diplomatic relations was celebrated in Ulaanbaatar and New Delhi. This provides us with a good opportunity to sum up our contemporary relations with India and to look into the future.

Today's India is one of the world's great nations in terms of population, territory, and gross national product. It is also one of the most influential countries in world politics and international organizations. It is for these reasons that India's policies toward and relations with China and Russia are so important to other Asian nations, and none more so than Mongolia. We should expand our present relations with India in such international bodies as the United Nations, the Group 77, and South-South Cooperation.

At the bilateral level, political and diplomatic ties have been strengthened. High-ranking officials of India have visited Mongolia, among them the president, the vice president, the speaker of the Look Saba, and Sonya Gandhi. Official Mongolian visitors to India have included the chairman of the presidium of the Great People's Khural, the president, the chairman of the council of ministers, and other ministers. During President Ochirbat's visit to India in February

\footnotetext{
${ }^{17}$ Nehru, speech given at the Fifteen Session of the UN General Assembly, October 3, 1960.

${ }^{18}$ Nehru, Glimpses of World History, 303.

${ }^{19}$ Nehru, Letters from a Father to his Daughter, 216.
} 
1994 a Treaty of Friendly Relations and Cooperation was signed which has served as the basic legal document guiding our two countries' relations. India has provided some important help, such as a 50 million rupee soft loan credit, awarding fifteen scholarships each year, and training Mongolian personnel in market economics, management, computer sciences, medium and small industries, and handicrafts. Yet much more can and should be done. For example, as of now only one joint venture exists, but there are great opportunities in Mongolia for Indian private companies to invest in more joint-venture projects. The brightest prospects lie in projects that will link Mongolia's mineral and agricultural resources to India's modern science and technology. 